\title{
Reasons Are Given for the Current Wildcat Strikes in Vietnam: The Blue-Collar Workers' Perspective
}

\author{
Hung Van Tran ${ }^{1}$ \\ ${ }^{1}$ Faculty of Business Administration, University of Finance and Marketing, Ho Chi Minh City, Vietnam \\ Correspondence: Hung Van Tran, Faculty of Business Administration, University of Finance and Marketing, Ho Chi \\ Minh City, Vietnam.
}

Received: June 20, 2019

Accepted: July 17, 2019

Online Published: July 17, 2019

doi:10.5430/ijfr.v10n4p90

URL: https://doi.org/10.5430/ijfr.v10n4p90

\begin{abstract}
Despite the vast research by researchers on Vietnam's wildcat strike, little is known of the perspective of the Southern Focal Economic Zone. The overall reason that emerges from the literature included: (1) raising wages for workers; (2) contributing to social security for workers; (3) and paying a seniority allowance. The aim of the present research is to figure out the reasons for the current wildcat strikes among Vietnamese blue-collar workers. A group of 936 Vietnamese blue-collar workers (387 males and 549 females) from four Southern Vietnam cities participated in the survey. They completed the Reasons are given for Wildcat Strikes questionnaire. The descriptive results showed that the highest mean among those reasons is "Labor regulations at the company are too strict". The result of this research emphasizes the impact of each reason by investigating nonoffice workers' perspective so as to predict which the potential reasons are for future strikes in Southern Vietnam.
\end{abstract}

Keywords: blue-collar wokers, economic zone, labor regulations, wildcat strikes, reasons, Vietnam

\section{Introduction}

Wildcat strikes have drawn much attention over the last three decades. They have played an important role in Vietnamese labor history (Chi \& Broek, 2013). A wildcat strike often referred to a strike action undertaken by unionized workers without union leadership's authorization, support, or approval (Blanc, 2019). On the ground that strikes in Vietnam rarely last long, it is dispensable for employers to propose legal intervention such as taking legal action against these strikes. Therefore, wildcat strikes are those that did not follow the procedures stipulated by the Vietnamese labor law (Anner \& Liu, 2016). Almost 80\% of strikes since 1995 have taken place in the foreign-invested enterprises in Southern Vietnam (Chi, 2008).

This article begins with a short review of the literature regarding the wildcat strikes in Vietnam. Many of the researchers reported that from 1995 to 2005, there were 978 recorded strikes (Clarke, Lee, \& Chi, 2007) and in 2011 the number reached the peak at 857 ones, which is the highest number recorded since the release of official strike figures (Siu \& Chan, 2015). According to official government statistics, there have been an estimated 300-500 recorded strikes per year since the mid-2000s (Anner, 2017). There have been numerous studies investigate the wildcat strikes in Vietnam (Chi \& Broek, 2013; Clarke, 2006; Clarke et al., 2007; Kerkvliet, 2011; Khanh, 2015; Nguyen, 2017; Siu \& Chan, 2015; Tran, 2007; Van Gramberg, Teicher, \& Nguyen, 2013).

Tran (2007) pointed out a more fundamental reason - the exploitative nature of the global production chain and the inability of the Vietnamese trade union federation (VGCL) to protect workers' rights (Tran, 2007). Clarke et al. (2007), on the other hand, agreed that the VGCL was on the side of workers, they pointed out that workers' demands had progressively shifted from struggling for legal rights to struggling for interests (Clarke et al., 2007). Kerkvliet (2011) has documented a comprehensive study of the strikes. Using a vast amount of documentary material, he showed that the majority of the strikes in 2006 occurred in foreign-run enterprises, particularly Taiwanese and South Korean ones. Workers went on strike mainly because of low wages, salaries paid in arrears, long working time and abusive management (Kerkvliet, 2011).

Although wildcat strikes are not a new topic, there are still a limited number of studies done in Vietnam, especially for on Vietnamese blue-collar workers. In order to fill this gap, this research is conducted to explore blue-collar workers' perception of wildcat strikes in Vietnam. The aim of this research is to measure the perception of Reasons 
are given for the current wildcat strikes in Vietnam among Vietnamese blue-collar workers.

The research starts with reviewing the empirical literature of blue-collar workers' perception of wildcat strikes. A simple analytical framework is introduced in the second section, followed by research methodology, result, and discussion. The last section is the conclusion.

\section{Methods}

\subsection{Data Collection}

The convenience sampling method was used to pick out Vietnamese blue-collar workers who volunteered to participate in the study and to administer the survey. The survey tools were distributed to 1200 Vietnamese blue-collar workers of companies located in Southern Focal Economic Zone, Vietnam, of which 983 questionnaires were returned, with a return rate of $81.9 \%$, which had exceeded the $30 \%$ response rate most researchers require for analysis (Dillman, 2000). The sample of this study was drawn from 936 respondents who completed the survey tools, including 387 males and 549 females. The researcher had contacted individual companies of each Industrial or Export Processing Zones prior to questionnaire distribution. The researcher contacted the representatives of each company and, with their consent, explained the purpose of the study before delivering questionnaires. Only if all participants were voluntarily willing to complete the questionnaires, the research was conducted. The amount of females that engaged in the survey among 936 low-waged workers including 605 workers from Industrial Zones and 331 workers from Export Processing Zones is 58.7\%, more than the one of males. Table 1 shows the distribution of participants in the Southern Focal Economic Zone, Vietnam.

Table 1. Number of participants in the study and percentage of population

\begin{tabular}{lll}
\hline & $n$ & $\%$ \\
\hline Area & & \\
\hline Tan Thuan Export Processing Zone & 111 & 11.8 \\
\hline Linh trung 2 Export Processing Zone & 126 & 13.46 \\
\hline Linh Trung 1 Export Processing Zone & 73 & 7.80 \\
\hline Le Minh Xuan Industrial Zone & 45 & 4.81 \\
\hline Vinh Loc Industrial Zone & 81 & 8.65 \\
\hline Industrial Zones in Ba Ria - Vung Tau & 150 & 16.03 \\
\hline Long Hau Industrial Zone & 164 & 17.52 \\
\hline Pou-Yuen Industrial Park & 92 & 9.83 \\
\hline Industrial Zones in Di An & 936 & 100 \\
\hline Total & & \\
\hline Age & 295 & 31.52 \\
\hline 18-25 years & 502 & 53.63 \\
\hline 26-35 years & 108 & 11.54 \\
\hline $36-45$ years & 31 & 3.31 \\
\hline$>$ 45 years & 936 & 100 \\
\hline Total & & \\
\hline Educational Background & 231 & 24.68 \\
\hline Completed lower secondary school & 347 & 37.07 \\
\hline Completed higher secondary school and higher & 210 & 22.44 \\
\hline Associate's degree & 148 & 15.81 \\
\hline Bachelor's and postgraduate degree & 936 & 100 \\
\hline Total & & \\
\hline & & \\
\hline
\end{tabular}




\subsection{Measurement}

Participants were asked to complete the Reasons are given for Wildcat Strikes (RGWS) questionnaire. All participants were instructed to read the questionnaire carefully and choose the responses that best described themselves. The questionnaire consists of 20 items measured on a single yes/no scale. Vietnamese blue-collar workers are asked to respond either 'Yes' or 'No' according to how well the questions describe them.

\subsection{Data Analysis}

Descriptive (Cohen, 1988) was performed by using the Statistical Package for the Social Sciences (SPSS) version 16.0. The percentages of responses for the survey scales and items were calculated. This analyse was used to explore blue-collar workers' perspective of Reasons are given for the current wildcat strikes in Viet Nam.

\section{Results}

According to the norms from the questionnaire, the participants scored in the percentage on the scale. The percentage of participants who answered 'yes' to each item ranged from $23.1 \%$ to $40.8 \%$. Table 2 shows the percentage distribution of workers for each reason given for the current wildcat strikes. The Reasons are given for the wildcat strikes have been grouped into 20 categories.

Table 2. Vietnamese blue-collar workers' perspective of Reasons are given for the current wildcat strikes

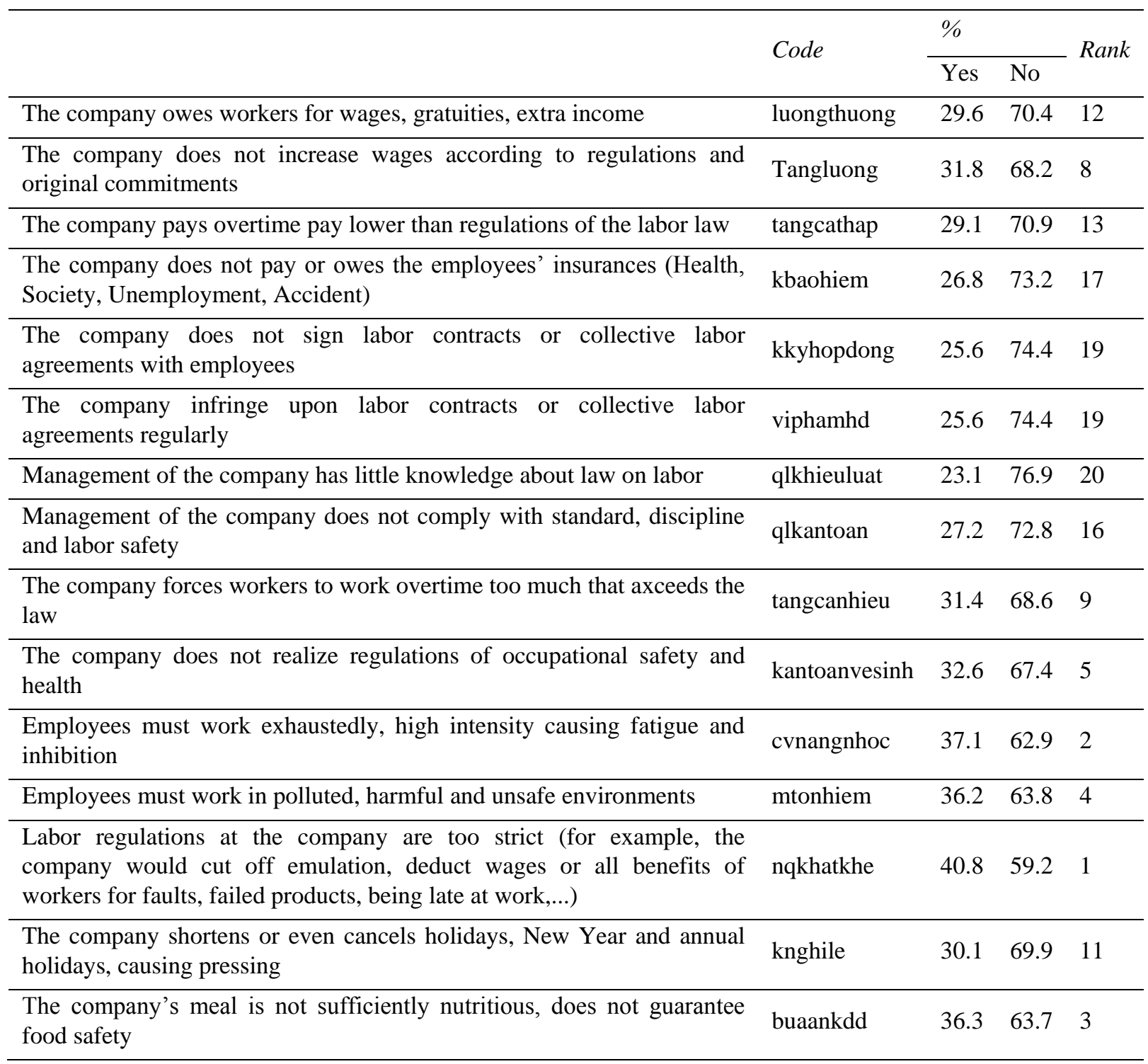




\begin{tabular}{lllll}
\hline Employees do not get free health care or sickness allowance & kchamsocsk & 28.7 & 71.3 & 15 \\
\hline The company uses non-transparent welfare fund, not intended & sdquykrorang & 29.0 & 71 & 14 \\
\hline Company leaders have cultural conflicts and dealings with employees & mauthuanvh & 32.2 & 67.8 & 7 \\
\hline Employees are offended at dignity, honour and constitution & xucpham & 32.5 & 67.5 & 6 \\
\hline $\begin{array}{l}\text { The company fires employees in contravention of regulations, tends to } \\
\text { retaliate }\end{array}$ & sathaikdung & 30.6 & 69.4 & 10 \\
\hline
\end{tabular}

The Figure 1 shows the percentage of respondents who answered 'yes'. In the population of 936 workers, $40.8 \%$ gave the answer that labor regulations at the company were too strict, (for example, the company would cut off emulation, deduct wages or all benefits of workers for faults, failed products, being late at work, ...), which is the highest percentage our survey had gotten. Meanwhile, only $23.1 \%$ of them claimed that management of the company had little knowledge about law on labor, which is the lowest numbers recorded.

The percentage of 'Labor regulations at the company are too strict' is respectively followed by the huge amount of work (37.1\%), low-nutrient meals (36.3\%), and polluted working environment $(36.2 \%)$. The following features are the lack of occupational safety and health, being offended, cultural conflicts and deals with around $32 \%$ per each reason. Of all the reasons, there are some reasons that hold the percentages in the range from $28 \%$ to $31 \%$, can be successively named: problems of healthcare and sickness allowance (28.7\%), non-transparent in using welfare fund (29\%), low pay for working overtime (29.1\%), being owed for wages, gratuities, extra income (29.6\%), insufficient holidays $(30.1 \%)$, unreasonable discharge $(30.6 \%)$, too much overtime $(31.4 \%)$ and no salary increase $(31.8 \%)$. Another uncommon cause are: management who didn't follow standard, discipline and labor safety (27.2\%), lack of employees' insurances (26.8\%) and issues of conferences (25\%). Those 20 causes indicate the blue-collar workers' assessment about reasons of unofficial strikes in Vietnam, and all of them have not surpassed 50\%.

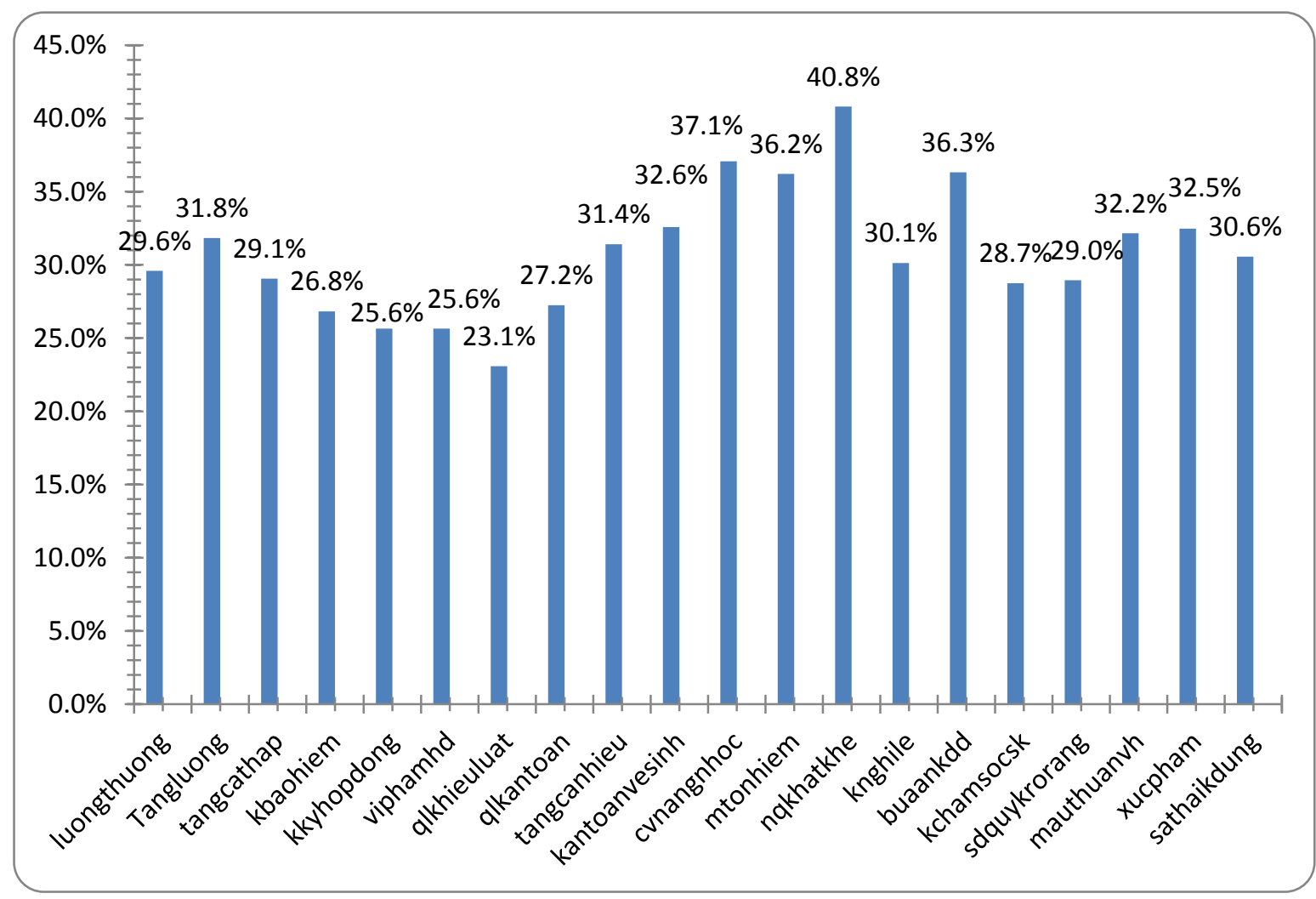

Figure 1. Percentage of participants who answered "yes" 
In this article, I have presented evidence to show that in addition to the many other reasons for a wildcat strike action to have become a normal facet of industrial relations in Vietnam. However, the vast majority of the Vietnamese blue-collar workers agreed that they are not satisfied with the labor regulations.

\section{Discussion}

This study indicates that workers' low satisfaction levels in Southern Focal Economic Zone, Vietnam with their salaries and earnings brought about wildcat strikes. The results, to some extend, share the parallel findings with previous studies. Korpi (1981) in his research concluded that the largest single category concerns Primarily piece-rates; also forms of piece-rates affecting earnings, unpaid wages, low wages due to technical failures new work methods, allowances, prolonged wage negotiations, etc accounting for close to half of all strikes. Anner (2017) concluded that salary increase is in great demand, proved by the fact that $41 \%$ of the low-waged workers desired to have a raise in their wages. Clarke et al. (2007) claimed that serious law breaking such as owing or reusing to pay, illegal discharge, insufficient pay for health insurances or wages and withholding on the bonuses were exposed by studying those out-law strikes. These findings were supported by Meissner and Hung (2008), besides, they added more reasons such as working overtime without any pay, compulsory excessive overtime and substandard accommodation and diet.

For the time being, the issue of 'wildcat strike', along with its effective regulation is more and more the hottest industrial relations issue in Vietnam. There is a urgent need for a scientific analysis of the this issue's causes as well as the exploration of practical policy options so as to address those strikes, as a new regulatory framework in the labor law will have a huge impact on the future trend of industrial relations development in Vietnam (Hoang, 2017). The very first aim that I conducted that study was to draw a conclusion that it is crucial to continuously reform the strike policy. To make this happen, some required conditions need applying: improving the legal framework in order to come up with strikes and dispute resolution strategies is a legal basics for enhancing the role of actors in labor relations so as to cut down on strikes; and if the strikes occurs, they are obligated to obey the provisions of law. Labor disputes could only be settled at the macro-level, which means an optimal solution is much more completing the legal system of labor than resolving issues at local level. That the legal framework needs improving is a matter of great urgency on the ground that this action would ensure a mechanism for cooperation, distribution of powers and responsibilities among the State, employers and employees.

Nevertheless, this research got some certain limitations. As the collecting data process only took place one time, it would hardly avoid existing limitations. To better observe the workers' change in attitudes over time, longitudinal study should be much more expedient. Furthermore, it is to our benefit to conduct qualitative research in an effort to access the workers' thoughts and feelings about those strikes. Besides, the fact those experts' vital roles are considered to be the most significant resources calls for another study on their perceptions of those causes.

\section{Conclusion}

To conclude, there are mainly 20 reasons that lead to wildcat strikes according to Vietnamese blue-collar workers' perception. As far as the authors concern, this is the initial research to consider the reasons of blue-collar workers' current wildcat strikes in Southern Focal Economic Zone, Vietnam. All the outcomes of this research are beneficial for the enhancing Vietnamese blue-collar workers' understanding of out-law strikes. The further expectation of conducting this research is to encourage more interests and investigations to bridge the gap between research and its practices.

\section{References}

Anner, M. (2017). Wildcat strikes and Better Work biparfite committees in Vietnam: Toward an elect, represent, protect and empower framework. Geneva: International Labour Office.

Anner, M., \& Liu, X. (2016). Harmonious unions and rebellious workers: A study of wildcat strikes in Vietnam. ILR Review, 69(1), 3-28. https://doi.org/10.1177/0019793915594596

Blanc, E. (2019). Red State Revolt: The Teachers' Strike Wave and Working-class Politics. New York: Verso.

Chi, D. Q. (2008). The challenge from below: Wildcat strikes and the pressure for union reform in Vietnam. Unpublished research report for a research project 'Post-Socialist Trade Unions, Low Pay and Decent Work: Russia, China and Vietnam'funded by the Economic and Social Research Council within its Non-Governmental Public Action Programme (Grant RES-155-25-0071).

Chi, D. Q., \& Broek, D. V. D. (2013). Wildcat strikes: A catalyst for union reform in Vietnam?. Journal of Industrial Relations, 55(5), 783-799. https://doi.org/10.1177/0022185613491685 
Clarke, S. (2006). The changing character of strikes in Vietnam. Post-Communist Economies, 18(3), 345-361. https://doi.org/10.1080/14631370600881796

Clarke, S., Lee, C.-H., \& Chi, D. Q. (2007). From rights to interests: The challenge of industrial relations in Vietnam. Journal of Industrial Relations, 49(4), 545-568. https://doi.org/10.1177/0022185607080321

Cohen, J. (1988). Set correlation and contingency tables. Applied Psychological Measurement, 12(4), 425-434. https://doi.org/10.1177/014662168801200410

Dillman, D. A. (2000). Mail and Internet surveys: The tailored design method. New York: John Wiley \& Sons.

Hoang, T. X. (2017). The solutions contribute to reduce the strike in current enterprises in Vietnam. International Journal of Economics, Business and Management Research, 1(1), 96-110.

Kerkvliet, B. J. (2011). Workers' protests in contemporary Vietnam. Labour in Vietnam (pp. 160-210). Singapore: Institute of Southeast Asian Studies. https://doi.org/10.1355/9789814311953-010

Khanh, T. L. (2015). The Right to Strike in Vietnam's Private Sector. Asian Journal of Law and Society, 2(1), 115-135. https://doi.org/10.1017/als.2015.2

Korpi, W. (1981). Unofficial strikes in Sweden. British Journal of Industrial Relations, 19(1), 66-86. https://doi.org/10.1111/j.1467-8543.1981.tb01098.x

Meissner, R., \& Hung, H. S. (2008). Private sector development, labor conflicts, and corporate governance in Vietnam-The search for new models. The Social and Ecological Market Economy-A Model for Asian Development? (pp. 267-287).

Nguyen, T. P. (2017). Legal Consciousness and Workers' Resistance in Đồng Nai Province, Vietnam. Asian Journal of Comparative Law, 12(2), 311-333. https://doi.org/10.1017/asjcl.2017.18

Siu, K., \& Chan, A. (2015). Strike wave in Vietnam, 2006-2011. Journal of Contemporary Asia, 45(1), 71-91. https://doi.org/10.1080/00472336.2014.903290

Tran, A. N. (2007). The third sleeve: Emerging labor newspapers and the response of the labor unions and the state to workers' resistance in Vietnam. Labor Studies Journal, 32(3), 257-279. https://doi.org/10.1177/0160449X07300716

Van Gramberg, B., Teicher, J., \& Nguyen, T. (2013). Industrial disputes in Vietnam: the tale of the wildcat. Asia Pacific Journal of Human Resources, 51(2), 248-268. https://doi.org/10.1111/j.1744-7941.2012.00062.x 